\title{
ベリリウム同位体を用いる堆積学的研究
}

\section{金井 豊 ${ }^{*}$}

\section{Sedimentological studies using beryllium isotopes}

\author{
Yutaka Kanai ${ }^{1 *}$
}

Sedimentological and geochemical studies using radioactive beryllium isotopes in the environment are reviewed. Their measurement methods are also explained. These nuclides have some characteristics such as their production in the atmosphere of the earth and continuous fall-down on the earth surface, usefulness as tracers owing to high affinity on the grain, radioactive clock of chronology for their own half-lives. Therefore, they have many extensive application studies; for example, the dating of surface/bottom sediments, continental/soil erosion, behaviors of sediments in the river/estuarine.

Key words: Beryllium, ${ }^{7} \mathrm{Be},{ }^{10} \mathrm{Be}$, geochemistry, review, sedimentology

\section{はじめに}

ベリリウム（Be）という元素は，一般には馴染みが少な いかもしれないが, 宝石のエメラルド, 緑柱石の主要構成 元素といわれれば理解しやすいだろう。ベリリウムは，原 子番号が 4 であり，自然界では陽子 4 個と中性子 5 個の質 量数 9 の核種 ${ }^{9} \mathrm{Be}$ のみが安定同位体として存在している. 一方，放射性同位体としては質量数が 7 と 10 の核種が存 在している. ${ }^{7} \mathrm{Be}$ および ${ }^{10} \mathrm{Be}$ は, 地球の大気上空に存在す る酸素（O）拈よび窒素（N）が, 宇宙線による核破砕反応 を受けることによって ${ }^{3} \mathrm{H}$ や ${ }^{14} \mathrm{C}$ ともに生成しており，そ の生成速度は太陽活動と関係しているといわれている。一 部の ${ }^{10} \mathrm{Be}$ は地表面の固体中でも生成される（次章を参 照). ${ }^{7} \mathrm{Be}$ は半減期 53.3 日で電子捕獲懐変 $(\mathrm{EC})$ をし, もう 一方の ${ }^{10} \mathrm{Be}$ は半減期 151 万年（139 万年？：後述参照）で

受付 : 2014 年 1 月 30 日 受理 : 2014 年 6 月 9 日

1 産業技術総合研究所 地質調査総合センター

干305-8567 茨城県つくば市東 1-1-1

Geological Survey of Japan, National Institute of Advanced Industrial Science and Technology (AIST), 1-1-1, Tsukuba, Ibaraki 305-8567, Japan

* Corresponding author: y.kanai@aist.go.jp $\beta^{-}$壊変をするというように, それぞれの壊変様式と半減 期は大きく異なっている.

これらの Be 核種は, 同位体としての共通性や，逆に放射 性核種としての特質の相違をうまく利用すると, 堆積学的 事象の解明に有用な役割を果たすと考えており, 著者らは 放射性同位体の一つ ${ }^{7} \mathrm{Be}$ を用いて堆積環境変化を解明する 研究を行っている (金井ほか, 2013)。これらの基本となっ ていることは, その生成が地球大気中で定常的に地表面に 降下していること, 土潩粒子等に対する親和性が高くその トレーサーとして有用であること, 放射性核種では「半減 期」という時計を有していること，などである。このため, 長短の半減期を有する $\mathrm{Be}$ の同位体を用いる応用研究は多 岐にわたり，様々な分野で広がりつつある.

本論文では, 堆積学・堆積地球化学の分野における $\mathrm{Be}$ の 同位体に関する応用研究を幾つか紹介したいと考えてい る. 読者の研究分野も様々で, 研究対象となる事象の夕イ ムスパンも幅広いが, 関連する研究の今後の参考となれば 幸いである。

ベリリウム-10

${ }^{10} \mathrm{Be}$ はその 151 万年（139 万年？：後述参照）という比 
較的長い半減期のために，長期にわたる地質事象のトレー サーとして利用されている. 即ち, 長い年代の時計として ゆっくりとした堆積速度や成長速度の研究, 古い堆積プロ セスの研究に利用できる.

地球表面に降下した大部分が大洋底に降り注ぐので, 堆 積速度が一定で二次的移動がないという仮定をおけば，核 種の減衰変化と時間との関係から約 1000 万年までの堆積 年代を算出できる（堀部純男編, 1975）。 また, 海洋底で成 長したマンガンノジュールに対しても， ウラン系列核種を 用いる ${ }^{230} \mathrm{Th} /{ }^{232} \mathrm{Th}$ 法や ${ }^{234} \mathrm{U} /{ }^{238} \mathrm{U}$ 法と同様に, ${ }^{10} \mathrm{Be}$ を利用 して成長速度が算出されている（Somayajulu, 1967）.

自生堆積物中の ${ }^{10} \mathrm{Be}$ を用いた年代測定では, ${ }^{10} \mathrm{Be}$ は壊 変して ${ }^{10} \mathrm{~B}$ となるが天然に元々存在している ${ }^{10} \mathrm{~B}$ と区別で きないため, U-Th 法, Rb-Sr 法, K-Ar 法のような親-娘核 種の減衰-成長関係を利用できない。 そこで, ${ }^{14} \mathrm{C}$ 年代と同 様な考えで, 1 試料の ${ }^{10} \mathrm{Be} /{ }^{9} \mathrm{Be}$ 比を用いる。 このような研 究目的では海底堆積物中の自生相を分別溶解法で抽出し, その中の ${ }^{10} \mathrm{Be} /{ }^{9} \mathrm{Be}$ 比を測定することで, 壊変定数入を用い た次式 (eq.(1))により, 一試料点の分析值から年代測定が なされる.

${ }^{10} \mathrm{Be} /{ }^{9} \mathrm{Be}=\left({ }^{10} \mathrm{Be} /{ }^{9} \mathrm{Be}\right)_{0} \cdot \exp \left(-\lambda_{10} \cdot \mathrm{t}\right) \quad$-------eq.(1) 後で述べるように ${ }^{10} \mathrm{Be} /{ }^{9} \mathrm{Be}$ 比は陸の影響を受けるので, 初 生 ${ }^{10} \mathrm{Be} /{ }^{9} \mathrm{Be}$ 比 $\left(\left({ }^{10} \mathrm{Be} /{ }^{9} \mathrm{Be}\right)_{0}\right)$ は場所によって異なるため, そ の地域での現世試料の值を代用しなければならない (Bourles et al., 1989; Lebatard et al., 2008).

陸上では, 土壤の年代測定・生成速度や地形面の形成・ 発達過程の研究に ${ }^{10} \mathrm{Be}$ が利用される。 この分野での ${ }^{10} \mathrm{Be}$ の適用法には 2 種類あり, 一つには海洋での研究例に示し たように高層大気中で生成した核種が地表面に降下して蓄 積したインベントリーが時間とともに変化することを利用 して解析する「Meteoric ${ }^{10} \mathrm{Be}$ 法」であり，もう一つは地表 面にある岩石表面の石英鉱物などの酸素に宇宙線が照射さ れて生成した ${ }^{10} \mathrm{Be}$ 量を利用する「in situ ${ }^{10} \mathrm{Be}$ 法」である. 我が国においては，前者による土䁃の年齢測定（前島・永 塚，2011）の研究例があり, 喜界島土壤の年齢が氷河性海 面変動曲線と平均隆起測線から推定される年齢とよく一致 していることを明らかにしている。 また，太陽活動や地球 環境によって高層大気での ${ }^{10} \mathrm{Be}$ 生成速度が影響を受ける ので, 水床・堆積物コアなどに記録されている過去の長期 にわたる太陽活動や地球磁場の変動を, 水床・コア中の ${ }^{10} \mathrm{Be}$ から探る研究として, 死海における後期更新世以降の 堆積物コアから ${ }^{10} \mathrm{Be}$ の生成速度の変動が調べられた例も ある (Belmarker et al., 2008). 後者による研究例としては, 青木（2000）が木曽山脈北部に分布するターミナルモレー ン構成堆積物に「in situ ${ }^{10} \mathrm{Be}$ 法」を適用して, 水成堆積物の 形成年代を報告している，後者についての詳細は，若狭ほ か（2004）に詳しい.このように,「in situ ${ }^{10} \mathrm{Be}$ 法」は氷河 期事象や沖積扇状地の表層, 河岸段丘 - 海岸段丘, 黄砂や 風成塵の履歴, 火山噴火, 地滑りなどの年代測定などにも 適用されている (Bierman et al., 2002).

宇宙線起源の ${ }^{10} \mathrm{Be}$ と大地の風化によって供給される安 定同位体 ${ }^{9} \mathrm{Be}$ を組み合わせた ${ }^{10} \mathrm{Be} /{ }^{9} \mathrm{Be}$ 比は, 大地の風化・ 侵食のパラメータとなり, 堆積学においては重要な指標の 一つである。一般に地中海のように陸からの寄与の大きな 海水ではこの比は低く, 太平洋のように降下 ${ }^{10} \mathrm{Be}$ 量が多く 陸からの寄与が小さい海水では大きい. このため, 大陸の 侵食速度の指標として ${ }^{10} \mathrm{Be} /{ }^{9} \mathrm{Be}$ 比を用いる研究が行われて いる. von Blanckenburg and Bouchez（2014）は, 海水の ${ }^{10} \mathrm{Be} /$ ${ }^{9} \mathrm{Be}$ 比が海洋の自生堆積物中に記録されているとしてこれ を解析し，過去から現在までの海洋への陸源物質のフラッ クスの指標としてこの比を利用した。 また, Willenbring and von Blanckenburg（2010）は，海洋に溶解した ${ }^{10} \mathrm{Be} /{ }^{9} \mathrm{Be}$ 比を 風化の代理指標として過去約 $12 \mathrm{Myr}$ にわたって再解析し, 新生代後期には安定した風化フラックスであったと結論づ けている。このように, ${ }^{10} \mathrm{Be}$ は長期にわたる堆積プロセス の研究に有用である.

これまでに述べてきた堆積プロセスの研究とは異なる ${ }^{10} \mathrm{Be}$ の活用例に，核実験調査がある。核爆発で発生する高 速中性子は大気中の二酸化炭素の ${ }^{13} \mathrm{C}$ と反応すると ${ }^{10} \mathrm{Be}$ が 生成する $\left({ }^{13} \mathrm{C}(\mathrm{n}, \alpha){ }^{10} \mathrm{Be}\right)$ 。 また, 構成物に B があるとそれ も原料となる。このため, ${ }^{10} \mathrm{Be}$ の存在は核爆発の一つの証 拠となる可能性がある。実際, 広島やカザフスタンでは バックグラウンドの 2-3 倍の過剩 ${ }^{10} \mathrm{Be}$ が観測されており, 半減期が長いので, 堆積物中に見いだされればそれは過去 の核実験活動を示す一つの指標になり得ることが示されて いる (Whitehead et al., 2008).

\section{ベリリウム-7}

${ }^{7} \mathrm{Be}$ は Arnord and Al-Salih（1955）により ${ }^{10} \mathrm{Be} よ り も 1$ 年 早く報告されている。彼らは, 地表 $15 \mathrm{~km}$ の上空で生成し た $\mathrm{BeO}$ もくは $\mathrm{Be}(\mathrm{OH})_{2}$ は拡散してダスト粒子に付着し, その後は大気中ダスト粒子として挙動をともにする, 即ち, それらは雲を作り降雨となって地表にもたらされると考え た。彼らは, シカゴで雨水を19-190リットル集めて初め て ${ }^{7} \mathrm{Be}$ を検出した. 1 年遅れて Goel et al.（1956）もボンベ イで同様に雨水から検出を行っている. ${ }^{7} \mathrm{Be}$ は半減期が 53.3 日と比較的短いだけで ${ }^{10} \mathrm{Be}$ の同位体であるから, ほと んどそれと類似した化学的挙動をとり, 数日〜数ヶ月の夕 イムスケールの気象や地質現象の解明にトレーサーとして 利用できる.

大気上層の酸素および窒素が宇宙線による核破砕反応を 
受けて生成し地表面に降ってくるため, ${ }^{7} \mathrm{Be}$ は空気中には 常時存在している。このため, 大気の動態を探る良い指標 となっている. その詳細研究は堆積学とは分野違いのため に省略するが, エアロゾル中の ${ }^{7} \mathrm{Be}$ の粒径分布や季節変動, フラックスやインベントリー等に関する研究が多くなされ ている（例えば, Bourcier et al., 2011; Caillet et al., 2001; Daish et al., 2005; Ioannidou, 2011; Jiwen et al., 2013; Renfro et al., 2013; Sanders et al., 2011; Wallbrink and Murray, 1994; Winkler et al., 1998).

地上に降り注いだ ${ }^{7} \mathrm{Be}$ は地表面で堆積するが, 建造物の 屋上の吹きだまりのような箇所では, ダスト粒子がそのま ま蓄積することがある。半隇期が短いので長時間経過して しまうと検出困難であるが, 堆積した表層部をみると検出 が可能である。通常の土壤・底質堆積物であれば, ${ }^{7} \mathrm{Be}$ が 検出されることはほとんど無く, また ${ }^{210} \mathrm{~Pb} も 0.1 \mathrm{~Bq} / \mathrm{g}$ の オーダーである (Kanai, 2009)，著者が調査した屋上の排水 溝やベランダの隅にたまった塵では, 2 3.6 Bq/g という比 較的高濃度の ${ }^{7} \mathrm{Be}$ が検出されており, 同時に測定された鉛 $-210\left({ }^{210} \mathrm{~Pb}\right)$ も 1.4 $5 \mathrm{~Bq} / \mathrm{g}$ と高濃度であった（Kanai, 2013). このような半減期の異なる 2 核種 $\left({ }^{7} \mathrm{Be}\right.$ は 53.3 日, ${ }^{210} \mathrm{~Pb}$ は 22.3 年）を用い, 定常的な堆積を仮定すれば, 塵の堆積後 の経過時間や古い土壤 ( ${ }^{7} \mathrm{Be}$ は不検出) との混合割合など を概算できる可能性が指摘されている（Kanai, 2013）.

海上に降下した ${ }^{7} \mathrm{Be}$ は, その半減期が短いために海水の 表層水のトレーサーとなりうる. Inoue et al.（2013）は, 日 本海の対馬海流に打ける移流パターンを解析するため に ${ }^{228} \mathrm{Ra}{ }^{226} \mathrm{Ra}$ と ${ }^{7} \mathrm{Be}$ を利用し, ${ }^{7} \mathrm{Be}$ は $50 \mathrm{~m}$ 以深で急激に濃 度が低下することから，下方への移動は少なく, $50 \mathrm{~m}$ 以浅 での平均滞留時間を 40-70 日と見積もっている.

一方，土壤粒子との吸着反応における $\mathrm{Be}$ の分配係数は 104-10 (Hawley et al., 1986; Steinmann et al., 1999) と大きい ので, ${ }^{7} \mathrm{Be}$ は降下物として地表に落ちると地表粒子に強く 結合し, その良いトレーサーとなる。地表面の堆積物や細 屑物は風雨に運搬されて河川に流れ込み, 河床や沿岸域に 堆積する. 従って, 堆積場の表層の堆積物には ${ }^{7} \mathrm{Be}$ が存在 している (Murray et al., 1992)。 ${ }^{7} \mathrm{Be}$ は半減期が短いため, 4 半減期に相当する約 200 日経過すると $1 / 16$ に減衰し検出 困難となる (Palinkas et al., 2005)。つまり，堆積物中に ${ }^{7} \mathrm{Be}$ が検出されるということは, 200 日以内に堆積した最新の 堆積物である証拠になる。我々は, ベトナムのメコンデル 夕から堆積物を採取し, その中の ${ }^{7} \mathrm{Be}$ を調べて堆積物の新 旧を解明した（金井ほか, 2013)。すなわち，雨季に採取し た表層堆積物では ${ }^{7} \mathrm{Be}$ が検出されたが下位では不検出であ り, その後の乾季では表層でも不検出となったことから, 新しい堆積物はなく表層堆積物が流失していることを明ら かにした。
${ }^{7} \mathrm{Be}$ に関しては, このような研究例の他にも, 地表面で の ${ }^{7} \mathrm{Be}$ のインベントリーを知ることができれば, 表層での 土壤の運搬·移動, 溶脱·蓄積などの短期的な地質作用の見 積もりが可能となる。.また, 海洋や沿岸域での堆積学研究 にも多く適用されており，環境中の ${ }^{210} \mathrm{~Pb}$ や ${ }^{137} \mathrm{Cs}$ などの他 の放射性核種と組み合わせて利用されることも多い。

例えば, ${ }^{7} \mathrm{Be}$ は時間の経過した底質では非常に濃度が低 く, 一方 ${ }^{210} \mathrm{~Pb}$ は底質でも浮遊物質でもほほ同程度である ことから, ${ }^{7} \mathrm{Be} /{ }^{210} \mathrm{~Pb}$ 比をとって調べれば再浮遊物質の量が 定量できる。 その一例として, Olsen et al. (1989) は, アメ リカ南東部に位置する Savannah Estuaryでの Pu の収支を 調べる研究に扔いて, ${ }^{7} \mathrm{Be} /{ }^{210} \mathrm{~Pb}$ 比を利用して懸濁物質の $80 \%$ 以上が底質の再浮遊であると見積もった。

当然のことながら, ${ }^{210} \mathrm{~Pb}$ と同様に堆積速度の算出も可 能であり, ${ }^{7} \mathrm{Be}$ は短い間の堆積速度を計算するために使用 できる。半減期の違う核種による堆積速度も比較検討する ことができ, 堆積物の輸送の動的な性質, 例えば堆積場の 定常性, 河川の汇濫や洪水, 嵐などのイベントが堆積過程 に果たしている重要な役割などを知ることができる。一例 として, ${ }^{7} \mathrm{Be}$ と ${ }^{210} \mathrm{~Pb}$ で求めた堆積速度が同程度であれば, その堆積場は長期にわたって安定であったことを示唆する ことから, Dibb and Rice（1989）は，チェサピーク湾では底 質の再分配があるものの, 堆積プロセスが過去 100 年間比 較的一定のままだったことを示した，逆に, Sommerfield et al.（1999）は, 北部カリフォルニアの大陸縁辺部の大陸棚 と斜面堆積物を調查し, 河川の流出がかなり多い洪水時 に7 Be が検出されることから河川堆積物の有力な指標とな ることを示し, 洪水堆積物が堆積履歴に大きなインパクト を与えていると結論づけた. Drexler and Nittrouer（2008） も, ローヌ川が流れ込む地中海に面した河口堆積物を調べ, 堆積層理や粘土含有量に変化がみられる洪水堆積物では, ${ }^{7} \mathrm{Be}$ が表層に存在し, ${ }^{210} \mathrm{~Pb}$ は希釈されて低濃度となってい ることなどを報告している.

このように, 我々の研究例と同様に沿岸域での ${ }^{7} \mathrm{Be}$ 応用 研究は多く, ミシシッピ川のデル夕域での底質 (Corbett et al., 2004）やウイスコンシンの Fox Rivwer 河川（Fitzgerald et al., 2001）などでの泥の輸送・堆積・再懸濁などのプロセ スの解明に, ${ }^{7} \mathrm{Be}$ の他に ${ }^{234} \mathrm{Th},{ }^{210} \mathrm{~Pb},{ }^{137} \mathrm{Cs}$ などの核種を組 み合わせて利用している. Murray et al. (1992) は，オース トラリアの Canberra の堆積物調查で, ${ }^{7} \mathrm{Be}$ の 9 割以上が湿 性沈着でもたらされて表層数ミリにしか存在しないことか ら, 河川粒子の ${ }^{7} \mathrm{Be}$ は表層堆積物の寄与を示唆しているこ とを報告し, 他にウラン・トリウム系列核種も計測してこ れらを輸送過程の研究のトレーサーとして利用している.

一方, ${ }^{7} \mathrm{Be}$ は大気から安定的に地表に降り注がれ, 土䁃 等の粒子に強く吸着することから, 水文学や地形学の分野 
でも広く応用されている，地形の侵食や農地の土壤流出な どは, 環境保全や農業生産などの施策と密接に絡んで重要 な課題の一つである。このような土壤の再移動・再分配の 研究には, 従来から様々な仮定を扔いて半減期の長い ${ }^{137} \mathrm{Cs}$ が用いられ (Mabit et al., 2013; Parsons and Foster, 2011, 2013)，そのインベントリーの大きさ，変動，分布を議論す る数多くの研究がなされ, 解析手法も確立してきている (IAEA, 1998; Porto et al., 2003; Soto and Navas, 2008). ${ }^{210} \mathrm{~Pb}$ との組み合わせ (Li et al., 2010; Walling et al., 2003), ${ }^{210} \mathrm{~Pb}$ と ${ }^{137} \mathrm{Cs}$ との組み合わせ (Bonniwell et al., 1999; Wallbrink. and Murray, 1996), ウラン系列核種を利用した研究例 （Dosseto et al., 2008; Murray et al., 1992）もあり, ${ }^{7} \mathrm{Be}$ を含め た環境中の放射性核種の利用はさらに広がりつつある (Walling, 2004; Zapata, 2003).

例えば，Walling et al.（1999）では耕作農地における土䁃 の再分配を明らかにするために ${ }^{7} \mathrm{Be}$ を使用した，彼らは ${ }^{7} \mathrm{Be}$ 抒よび ${ }^{137} \mathrm{Cs}$ のインベントリーの分布様式が類似して いることから, 侵食も蓄積も起こっていない対照地と嵐前 後のインベントリーを比較して, 短い (数日), イベント的 な，もしくは中期的（数十年間）な夕イムスケールで起き た土壤損失抒よび蓄積のエリアを識別している. Sepulveda et al. (2008) は, 2005 年 5 月にチリで起こった 27 日間に $400 \mathrm{~mm}$ という豪雨による耕作地の侵食を, 半減期 の短い ${ }^{7} \mathrm{Be}$ を利用して解明している. Bonniwell et al. （1999）も，堆積物のトレーサーとして ${ }^{7} \mathrm{Be},{ }^{210} \mathrm{~Pb},{ }^{137} \mathrm{Cs}$ を 利用したが, Gold Fork River（アイダホ）の小さな分水界に おける水カラムの中に川底から再懸濁される「古い」堆積 物では ${ }^{7} \mathrm{Be}$ が無視できるとして, 雪解け水の「新しい」堆 積物の指標として ${ }^{7} \mathrm{Be}$ を使用し, 土壤へのインベントリー との比較から平均侵食速度を $2.3 \mathrm{~mm} / \mathrm{y}$ と求めている.

また， ${ }^{7} \mathrm{Be}$ ，過剩 ${ }^{210} \mathrm{~Pb}$ 抢よび ${ }^{137} \mathrm{Cs}$ は地表土䁃において 異なる梁度分布パターンを示すことから, 懸濁堆積物が土 畩のどの部位に由来したのか, どのようなタイプの侵食が 行われたか（例えば, シートフローか, 細溝（リル）侵食 か, ガリー侵食か)，などを推測する手立てとして利用でき る. Wallbrink and Murray（1993）は，これらの核種を利用 してシートフローでは 3 核種が懸濁物中に高濃度である が，リル侵食になると ${ }^{137} \mathrm{Cs}$ が卓越し ${ }^{7} \mathrm{Be}$ と ${ }^{210} \mathrm{~Pb}$ が時間と ともに減少する傾向にあることを示している，また，土壤 に打ける 3 核種による ${ }^{7} \mathrm{Be}^{-210} \mathrm{~Pb}$ と ${ }^{210} \mathrm{~Pb}^{-137} \mathrm{Cs}$ の深度プロ ファイルを用いて，起源となる各層を解析する手法が提案 されている (Wallbrink et al., 1999).

\section{Be 同位体の測定法}

さて, 次に Be 同位体の測定法について触れておこう.
安定同位体の ${ }^{9} \mathrm{Be}$ は比較的低濃度であるが普遍的に存在し ている. ${ }^{9} \mathrm{Be}$ 濃度は Wedepohl（1995）による上部大陸地殼 の平均存在度は約 $3.1 \mathrm{ppm}$ 程度で, 日本の河川堆積物の平 均濃度は $1.4 \mathrm{ppm}$ とされている (今井ほか, 2004)。この程 度の濃度は ICP や ICP-MS で検出可能である。一方，放射 性の ${ }^{10} \mathrm{Be}$ は濃度が低い上に半減期が非常に長い核種であ るために, 比放射能（核種 $1 \mathrm{~g}$ あたりの放射能）は非常に低 いので，通常の放射能測定は不可能に近い．例えば， ${ }^{10} \mathrm{Be}$ を最初に報告した Arnold（1956）は海の底質中濃度を 0.03 $\mathrm{Bq} / \mathrm{cm}^{2}$ としているが，これは 1 分間に 2 回の壊変が㧍こる 程度である. 赤粘土中の約 $0.1 \mathrm{mBq} / \mathrm{cm}^{3}$ という濃度は 3 時 間に 1 回の壊変ということになる。このため, ${ }^{10} \mathrm{Be}$ の定量 には放射能ではなく, 核種の数を直接計測する加速器質量 分析法 (AMS 法) が用いられる. AMS 法は 1970 年代末に 開発され，1980 年代になって普及し始め, さらに 1990 年 代には検出下限も 1 桁下がって高感度化したため, 研究も 活性化した。

AMS 法では, 放射性同位体核種と安定同位体核種をイ オン源でイオン化し, タンデム加速器で加速し, 加速した イオンのエネルギーや質量によって妨害イオンと選別を 行った後に, ファラデーカップや重イオン検出器で測定す る. 前者の検出器は安定同位体を電流值として定量し, 後 者は放射性核種を個数として計数する. 質量分析法では, 同重体である ${ }^{10} \mathrm{~B}$ などは妨害イオンとなるので特に注意し なければならない，定量は標準試料との比較法でなされ， 感度としては ${ }^{10} \mathrm{Be} /{ }^{9} \mathrm{Be}$ 比で $3 \times 10^{-15} \sim 5 \times 10^{-14}$ とされる (永井ほか, 1991; 中村, 2003; Matsuzaki et al., 2007).

試料は Be としてわずか $0.1-0.5 \mathrm{mg}$ と少量でよいが，前 処理としてイオン化するのに適した形に調製する必要があ る. まず，試料を分解後キャリアーとして ${ }^{9} \mathrm{Be}$ を加え，妨 害となる他の元素からイオン交換法などによって分離精製 する. 特に, 同重体である ${ }^{10} \mathrm{~B}$ には注意が必要で, $\mathrm{Be}$ 水酸 化物の沈殿生成, 溶解と再沈殿を繰り返して分離精製する. これを焼いて $\mathrm{BeO}$ とし， $\mathrm{Nb}$ 粉と混合してターゲットとす る(永井ほか, 1991; Matsuzaki et al., 2004, 2007; 横山ほか, 2005). ターゲットに $\mathrm{Cs}^{+}$ビームを照射して $\mathrm{BeO}^{-}$イオン をたたき出し，AMS システムで測定する.

ちなみに, 我が国では東大・筑波大・名古屋大・山形大・ 国立環境研・日本原子力研究開発機構などで, 更新・予定 も含め 9 台の AMS 装置が稼働中というが, ほとんどが ${ }^{14} \mathrm{C}$ 専用機である(若狭ほか, 2004; 東京大学, 2013)。サイク ロトロン AMS, タンデム AMS のどちらのタイプでも ${ }^{14} \mathrm{C}$ だけでなく ${ }^{10} \mathrm{Be}$ の測定が可能であるが (中村, 2003), 実際 に ${ }^{10} \mathrm{Be}$ の測定が可能な装置は, 2013 年現在においては東 大の MALT と建設中の筑波大に限られているようである (若狭, 2013)。今後は ${ }^{14} \mathrm{C},{ }^{10} \mathrm{Be}$ の他にも, ${ }^{26} \mathrm{Al},{ }^{36} \mathrm{Cl},{ }^{41} \mathrm{Ca}$, 
${ }^{129} \mathrm{I}$ なども測定できる多目的タンデム AMS が有望になり つつある。

ところで，本論文中では ${ }^{10} \mathrm{Be}$ の半隇期を 151 万年 (139 万年？）と記述してきた．これは，151万年という記述が これまでは多かったが, 近年 1 割ほど短く見直される傾向 にあるからである。近年になって AMS 測定がより簡単に 高精度で行えるようになると, Fink and Smith (2007), Nishiizumi et al. (2007), Korschinek et al. (2010), Chmeleff et al. (2010) などが $143 \pm 10$ 万年, $136 \pm 7$ 万年, $138.8 \pm 1.8$ 万 年，138.6土1.6万年というように，以前よりもだいぶ短め な半減期を報告してきており，抒そらくこれらが真值に近 いものではないかと推定される. National Nuclear Data Center の Evaluated Nuclear Structure Data File (ENSDF) の ホームページでも, ${ }^{10} \mathrm{Be}$ の半減期として $1.387 \mathrm{E}+6 \mathrm{y}$ とい う記述がなされている（ENSDF, 2014）。

これに対し, 放射線測定は半隇期の短い ${ }^{7} \mathrm{Be}$ に有効で, ${ }^{7} \mathrm{Be}$ の場合には ECに伴う $478 \mathrm{keV}$ のガンマ線（放出率 10 \%）を計測して定量する. エネルギー弁別の可能なゲルマ ニウム半導体検出器を用いると, 特別な前処理をせず容易 にウラン系列核種, トリウム系列核種や ${ }^{137} \mathrm{Cs}$ と同時測定 可能である. 試料量が少なく濃度の低い試料では, 検出効 率の高い井戸型のゲルマニウム半導体検出器が効果的で, 著者らはこれを用いて放射線測定を行っている．壊変定数 $\lambda$ ，ガンマ線の放出率や種々の補正係数を含んだ検出効率 $\varepsilon$, 核種の数 $\mathrm{N}$, 半減期を $\mathrm{T}_{1 / 2}$ とすると, その計数率 $\mathrm{n}$ は次 式 (eq.(2)）に示されるように,

$$
\mathrm{n}=\lambda \cdot \varepsilon \cdot \mathrm{N}=\left[\ln (2) / \mathrm{T}_{1 / 2}\right] \cdot \varepsilon \cdot \mathrm{N}
$$

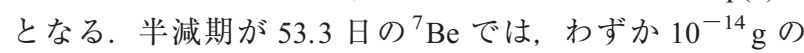
${ }^{7} \mathrm{Be}$ が存在すれば, 仮に $\varepsilon$ が 0.03 程度でもそのガンマ線は 毎秒数カウントになる。 一方, 同量の ${ }^{10} \mathrm{Be}$ が存在したとし ても半減期に $10^{7}$ 倍の違いがあるので, $\varepsilon$ の相違を考慮し ても $1 / 10^{6}$ 倍ほどの計数率の違いとなり， 4 日に 1 カウント 程度である. 中村 (2003) は, $1 \mathrm{mg}$ の NBS ベリリウム標準 体 $\left({ }^{10} \mathrm{Be} /{ }^{9} \mathrm{Be}=3.1 \times 10^{-11}\right)$ を用いた放射能測定では 1 時間 で 0.11 カウントにすぎないが, AMS 測定では 68400 カウ ントが可能であるとして， ${ }^{10} \mathrm{Be}$ に対する AMS 測定の有効 性を説いている.

${ }^{7} \mathrm{Be}$ の放射線測定で不都合な点を一つあげるとすれば, 半減期が短いために迅速な測定作業が必要ということであ ろう。実際，著者らが海外のデル夕地域から底質を採取し て, 乾燥・微粉砕などの前处理をして最初の試料測定開始 までに約 2 週間を要し, 1 回の測定時間を 3〜4 日間として 数試料を測定し終える時には ${ }^{7} \mathrm{Be}$ の半減期を超える約 2 ケ 月が経過していた．数多くの試料を扱うと後半の試料測定 時までにかなり時間経過があり（2ヶ月以上，それによる 減衰と検出限界の上昇とにより，すべての試料で有意の值
を確認することは困難となる。このため，今後は更なる手 順の迅速化, 測定のマルチ化などを検討する必要があろう.

\section{おわりに}

本論では, ベリリウム，特に放射性ベリリウム同位体で ある ${ }^{10} \mathrm{Be}$ と ${ }^{7} \mathrm{Be}$ に関して, 地質学, 堆積地球化学に応用し た研究例を幾つか解説, 紹介してみた. 半減期の長短によ る測定法の相違やその研究例の共通点と相違点など, 様々 なことが理解していただけたと思う。半減期の相違をうま く利用すると, 長いタイムスパンの事象や逆に短いタイム スパンの事象などを解明する指標となり, プロセスの解明 に有用な手段となるなど, ベリリウム核種を堆積学分野に 応用して得られた結果には貴重な情報が多く含まれ，時間 の軸を織り込んだ解釈が可能である。 今後の幅広い活用が 期待される.

また, 測定に関しては ${ }^{10} \mathrm{Be}$ では近年分析精度が格段に進 展したが, 大がかりで高価な AMS も必要であることから, 今後は共同利用化をさらに進めるとともに，より多くの情 報を得るために ${ }^{26} \mathrm{Al},{ }^{36} \mathrm{Cl},{ }^{41} \mathrm{Ca},{ }^{129} \mathrm{I}$ なども測定できる多 目的タンデム AMS を活用することが主体となっていくも のと思われる. ${ }^{7} \mathrm{Be}$ に関しても, 多数の試料が迅速に測定 できるようなシステムを作っていくことが重要と思われ る.

謝辞 : 本研究を進めるに当たって地質調查総合センターの 斎藤文紀氏を初めとして研究グループの方々のご支援, ご 協力を賜った．本粗稿に対して，日本大学の永井尚生氏並 びに匿名の査読者や編集委員である信州大学の吉田孝紀氏 から, 数々の貴重なコメントをいただいた。ここに記して 深く感謝申し上げる.

\section{文献}

青木賢人, $2000,{ }^{10} \mathrm{Be}$ 露出年代法を用いた氷成堆積物の形成年代 の測定一木曽山脈北部, 千畳敷カール, 濃ヶ池カールの事例一. 第四紀研究，39, 189-198.

Arnold, J.R., 1956, Beryllium-10 produced by cosmic rays. Science, 124, 584-585.

Arnold, J.R. and Al-Salih, H.A., 1955, Beryllium-7 produced by cosmic rays. Science, 121, 451-453.

Belmarker, R., Lazar, B., Tepelyakov, N., Stein, M. and Beer, J., $2008,{ }^{10} \mathrm{Be}$ in Lake Lisan sediments-A proxy for production or climate. Earth and Planetary Science Letters, 269, 447-456.

Bierman, P.R., Caffee, M.W., Davis, P.T., Marsella, K., Pavich, M., Colgan, P., Mickelson, D. and Larsen, J., 2002, 4 Rates and timing of earth surface processes from in situ-produced cosmogenic Be- 
10. Reviews in mineralogy and geochemistry, 50, 147-205.

Bonniwell, E.C., Matisoff, G. and Whiting, P.J., 1999, Determining the times and distances of particle transit in a mountain stream using fallout radionuclides. Geomorphology, 27, 75-92.

Bourcier, L., Masson, O., Laj, P., Pichon, J.M., Paulat, P., Freney, E. and Sellegri, K., 2011, Comparative trends and seasonal variation of ${ }^{7} \mathrm{Be},{ }^{210} \mathrm{~Pb}$ and ${ }^{137} \mathrm{Cs}$ at two altitude sites in the central part of France. Journal of Environmental Radioactivity, 102, 294-301.

Bourles, D., Raisbeck, G.M. and Yiou, F., $1989,{ }^{10} \mathrm{Be}$ and ${ }^{9} \mathrm{Be}$ in marine sediments and their potential for dating. Geochimica et Cosmochimica Acta, 53, 443-452.

Caillet, S., Arpagaus, P., Monna, F. and Dominik, J., 2001, Factors controlling ${ }^{7} \mathrm{Be}$ and ${ }^{210} \mathrm{~Pb}$ atmospheric deposition as revealed by sampling individual rain events in the region of Geneva, Switzerland. Journal of Environmental Radioactivity, 53, 241-256.

Chmeleff, J., von Blanckenburg, F., Kossert, K. and Jakob, D., 2010, Determination of the ${ }^{10} \mathrm{Be}$ half-life by multicollector ICP-MS and liquid scintillation counting. Nuclear Instruments and Methods in Physics Research B, 268, 192-199.

Corbett, D.R., McKee, B. and Duncan, D., 2004, An evaluation of mobile mud dynamics in the Mississippi River deltaic region. Marine Geology, 209, 91-112.

Daish, S.R., Dale, A.A., Dale, C.J., May, R. and Rowe, J.E., 2005, The temporal variations of ${ }^{7} \mathrm{Be},{ }^{210} \mathrm{~Pb}$ and ${ }^{210} \mathrm{Po}$ in air in England. Journal of Environmental Radioactivity, 84, 457-467.

Dibb, J.E. and Rice, D.L., 1989, Temporal and spatial distribution of beryllium-7 in the sediments of Chesapeake Bay. Estuarine, Coastal and Shelf Science, 28, 395-406.

Dosseto, A., Bourdon, B. and Turner, S.P., 2008, Uranium-series isotopes in river materials: Insights into the timescales of erosion and sediment transport. Earth and Planetary Science Letters, 265, 1-17.

Drexler, T.M. and Nittrouer, C.A., 2008, Stratigraphic signatures due to flood deposition near the Rhone River: Gulf of Lion, northwest Mediterranean Sea. Continental Shelf Research, 28, 1877-1894.

ENSDF, 2014, NuDat 2.6. (http://www.nndc.bnl.gov/nudat2/reCenter. jsp?z=4\&n=6) (2014/1/27 アクセス $)$

Fink, D. and Smith, A., 2007, An inter-comparison of ${ }^{10} \mathrm{Be}$ and ${ }^{26} \mathrm{Al}$ AMS reference standards and the ${ }^{10} \mathrm{Be}$ half-life. Nuclear Instruments and Methods in Physics Research B, 259, 600-609.

Fitzgerald, S.A., Klump, J.V., Swarzenski, P.W., Mackenzie, R.A. and Richards, K.D., 2001, Beryllium-7 as a tracer of short-term sediment deposition and resuspension in the Fox River, Wisconsin. Environmental Science and Technology, 35, 300-305.

Goel, P.S., Jha, S., Lal, D., Radhakrishna, P. and Rama, 1956, Cosmic ray produced beryllium isotopes in rain water. Nuclear Physics, $\mathbf{1}$, 196-201.

Hawley, N., Robbins, J.A. and Eadie, B.J., 1986, The partitioning of ${ }^{7}$ beryllium in fresh water. Geochimica et Cosmochimica Acta, 50, $1127-1131$.

堀部純男編, 1975, 海洋学講座 6, 海洋無機化学, 東京大学出版
会, 202 p.

IAEA, 1998, Use of ${ }^{137} \mathrm{Cs}$ in the study of soil erosion and sedimentation. IAEA, Vienna, 1998, IAEA-TECDOC-1028.

今井 登, 寺島 滋, 太田充恒, 御子柴 (氏家) 真澄, 岡井貴司, 立花好子, 富樫茂子, 松久幸敬, 金井 豊, 上岡 晃, 谷口 政碩, 2004, 日本の地球化学図. 産業技術総合研究所地質調 査総合センター, 209 p.

Inoue, M., Furusawa, Y., Fujimoto, K., Minakawa, M., Kofuji, H., Nagao, S., Yamamoto, M., Hamajima, Y., Yoshida, K.,Nakano, Y., Hayakawa, K. and Oikawa, S., 2013, ${ }^{228} \mathrm{Ra} /{ }^{226} \mathrm{Ra}$ ratio and ${ }^{7} \mathrm{Be}$ concentration in the Sea of Japan as indicators for water transport: comparison with migration pattern of Fukushima Dai-ichi NPPderived ${ }^{134} \mathrm{Cs}$ and ${ }^{137} \mathrm{Cs}$. Journal of Environmental Radioactivity, 126, 176-187.

Ioannidou, A., 2011, Activity size distribution of ${ }^{7} \mathrm{Be}$ in association with trace metals in the urban area of the city of Thessaloniki, Greece. Atmospheric Environment, 45, 1286-1290.

Jiwen, L., Starovoitova, V.N. and Wells, D.P., 2013, Long-term variations in the surface air ${ }^{7} \mathrm{Be}$ concentration and climatic changes. Journal of Environmental Radioactivity, 116, 42-47.

Kanai, Y., 2009, Fluxes and inventories of ${ }^{210} \mathrm{~Pb}$ and ${ }^{137} \mathrm{Cs}$ in lake sediments from East Asia and their relationships to sedimentary environment. Journal of the Sedimentological Society of Japan, $\mathbf{6 8}$, 91-103.

Kanai, Y., 2013, High activity concentrations of ${ }^{210} \mathrm{~Pb}$ and ${ }^{7} \mathrm{Be}$ in sediments and their histories. Journal of Environmental Radioactivity, 124, 44-49.

金井 豊, 斎藤文紀, 田村 亨, Nguyen, V.L., Ta, T.K.O, 佐藤明 夫, 2013, メコンデルタ堆積物におけるベリリウム-7, 鉛210 及び放射性セシウム同位体の分布と堆積環境の季節変 化. 地球化学, 47, 89-100.

Korschinek, G., Bergmaier, A., Faestermann, T., Gerstmann, U.C., Knie, K., Rugel, G., Wallner, A., Dillmann, I., Dollinger, G., von Gostomski, C.L., Kossert, K., Maiti, M., Poutivtsev, M. and Remmert, A., 2010, A new value for the half-life of ${ }^{10} \mathrm{Be}$ by Heavy-Ion Elastic Recoil Detection and liquid scintillation counting. Nuclear Instruments and Methods in Physics Research $B, \mathbf{2 6 8}, 187-191$.

Lebatard, A-E, Bourle, D.L., Duringer, P., Jolivet, M., Braucher, R., Carcaillet, J., Schuster, M. and Arnaud, N., 2008, Cosmogenic nuclide dating of Sahelanthropus tchadensis and Australopithecus bahrelghazali: Mio-Pliocene hominids from Chad. PNAS, 105, 3226-3231.

Li, M., Yao, W., Li, Z., Liu, P. and Shen, Z., 2010, Effect of landforms on the erosion rate in a small watershed by the ${ }^{137} \mathrm{Cs}$ tracing method. Journal of Environmental Radioactivity, 101, 380-384.

Mabit, L., Meusburger, K., Fulajtar, E. and Alewell, C., 2013, The usefulness of ${ }^{137} \mathrm{Cs}$ as a tracer for soil erosion assessment: A critical reply to Parsons and Foster (2011). Earth-Science Reviews, 127, 300-307.

前島勇治, 永塚鎮男, 2011, 南西諸島に分布するサンゴ石灰岩上 
の土壤の年齢. 地球環境, $\mathbf{1 6}, 169-177$.

Matsuzaki, H., Nakano, C., Yamashita, H., Maejima, Y., Miyairi, Y., Wakasa, S. and Horiuchi, K., 2004, Current status and future direction of MALT, The University of Tokyo. Nuclear Instruments and Methods in Physics Research Section B: Beam Interactions with Materials and Atoms, 223-224, 92-99.

Matsuzaki, H., Nakano, C., Tsuchiya (Sunohara), Y., Kato, K., Maejima, Y., Miyairi,Y., Wakasa, S. and Aze, T., 2007, Multi-nuclide AMS performances at MALT. Nuclear Instruments and Methods in Physics Research Section B: Beam Interactions with Materials and Atoms, 259, 36-40.

Murray, A.S., Olley, J.M. and Wallbrink, P.J., 1992, Natural radionuclide behavior in the fluvial environment. Radiation Protection Dosimetry, 7, 297-304.

永井尚生, 今村峯雄, 小林紘一, 吉田邦夫, 大橋英雄, 山下 博, 1991 , 加速器質量分析による ${ }^{10} \mathrm{Be}$ と ${ }^{26} \mathrm{Al}$ の測定. 質量分析, 39, 315-327.

中村俊夫, 2003, I. 加速器質量分析 (AMS) による環境中および トレーサ放射性同位体の高感度測定. Radioisotopes, 52, 145171.

Nishiizumi, K., Imamura, M., Caffee, M.W., Southon, J.R., Finkel, R.C. and McAninch, J., 2007, Absolute calibration of ${ }^{10} \mathrm{Be}$ AMS standards. Nuclear Instruments and Methods in Physics Research $B, \mathbf{2 5 8}, 403-413$.

Olsen, C.R., Thein, M., Ingvar, L., Larsen, I.L., Lowry, P.D., Mulholland, P.J., Cutshall, N.H., Byrd, J.T. and Windom, H.L., 1989, Plutonium, lead-210, and carbon isotopes in the Savannah estuary: riverborne versus marine sources. Environmental Science and Technology, 23, 1475-1481.

Palinkas, C.M., Nittrouer, C.A., Wheatcroft, R.A. and Langone, L., 2005, The use of ${ }^{7} \mathrm{Be}$ to identify event and seasonal sedimentation near the Po River delta, Adriatic Sea. Marine Geology, 222-223, 95-112.

Parsons, A.J. and Foster, I.D.L., 2011, What can we learn about soil erosion from the use of ${ }^{137} \mathrm{Cs}$ ? Earth-Science Reviews, 108, 101113.

Parsons, A.J. and Foster, I.D.L., 2013, The assumptions of science A reply to Mabit et al. (2013). Earth-Science Reviews, 127, 308-310.

Porto, P., Walling, D.E., Tamburino, V. and Callegari, G., 2003, Relating caesium-137 and soil loss from cultivated land. Catena, 53, 303-326.

Renfro, A.A., Cochran, J.K. and Colle, B.A., 2013, Atmospheric fluxes of ${ }^{7} \mathrm{Be}$ and ${ }^{210} \mathrm{~Pb}$ on monthly time-scales and during rainfall events at Stony Brook, New York (USA). Journal of Environmental Radioactivity, 116, 114-123.

Sanders, C.J., Smoak, J.M., Cable, P.H., Patchineelam, S.R. and Sanders, L.M., 2011, Lead-210 and beryllium-7 fallout rates on the southeastern coast of Brazil. Journal of Environmental Radioactivity, 102, 1122-1125.

Sepulveda, A., Schuller, P., Walling, D.E. and Castillo, A., 2008, Use of ${ }^{7} \mathrm{Be}$ to document soil erosion associated with a short period of extreme rainfall. Journal of Environmental Radioactivity, 99, 3549.

Somayajulu, B.L.K., 1967, Beryllium-10 in a manganese nodule. Science, 156, 1219-1220.

Sommerfield, C.K., Nittrouer, C.A. and Alexander, C.R., 1999, ${ }^{7}$ Be as a tracer of flood sedimentation on the northern California continental margin. Continental Shelf Research, 19, 335-361.

Soto, J. and Navas, A., 2008, A simple model of Cs-137 profile to estimate soil redistribution in the cultivated stony soils. Radiation Measurement, 43, 1285-1293.

Steinmann, P., Billen, T., Loizeau, J.-L. and Dominik, J., 1999, Beryllium-7 as a tracer to study mechanisms and rates of metal scavenging from lake surface waters. Geochimica et Cosmochimica Acta, 63, 1621-1633.

東京大学, 2013, 2013 東京大学タンデム加速器研究施設 概要 MALT (Micro Analysis Laboratory, Tandem accelerator, The University of Tokyo) (2013.12.09) http://malt.n.t.u-tokyo.ac.jp/MALT status/MALTsummary131209.pdf（2014/1/27 アクセス）

von Blanckenburg, F. and Bouchez, J., 2014, River fluxes to the sea rom the ocean's ${ }^{10} \mathrm{Be} /{ }^{9} \mathrm{Be}$ ratio. Earth and Planetary Science Letters, 387, 34-43.

若狭 幸, 2013, 原位置宇宙線生成核種を用いた地表面の年代測 定一考古学分野への応用の可能性一, フィッション・トラッ ク ニュースレター, 26, 63-66.

若狭 幸, 松崎浩之, 松倉公憲, 2004, 原位置宇宙線生成核種年 代測定法 : 侵食地形変化速度の解明への適用. 地形, 25, 247265.

Wallbrink, P.J. and Murray, A.S., 1993, Use of fallout radionuclides as indicators of erosion processes. Hydrological Processes, 7, 297304.

Wallbrink, P.J. and Murray, A.S., 1994, Fallout of Be-7 in south Eastern Australia. Journal of Environmental Radioactivity, 25, 213-228.

Wallbrink, P.J. and Murray, A.S., 1996, Determining soil loss using the inventory ratio of excess lead-210 to cesium-137. Soil Science Society of America Journal, 60, 1201-1208.

Wallbrink, P.J., Murray, A.S. and Olley, J.M., 1999, Relating suspended sediment to its original soil depth using fallout radionuclides. Soil Science Society of America Journal, 63, 369-378.

Walling D.E., 2004, Using environmental radionuclides to trace sediment mobilization and delivery in river basins as an aid to catchment management. Proceedings of the Ninth International Symposium on River Sedimentation, Oct. 18-21, 2004, Yichang, China.

Walling, D.E., He, Q. and Blake, W., 1999, Use of ${ }^{7} \mathrm{Be}$ and ${ }^{137} \mathrm{Cs}$ measurements to document short- and medium-term rates of waterinduced erosion on agricultural land. Water Resources Research, 35, 3865-3874.

Walling, D.E., Collins, A.L. and Sichingabula, H.M., 2003, Using unsupported lead-210 measurements to investigate soil erosion and sediment delivery in a small Zambian catchment. Geomorphology, 52, 193-213.

Wedepohl, K.H., 1995, The composition of the continental crust. Geo- 
chimica et Cosmochimica Acta, 59, 1217-1232.

Whitehead, N.E., Endo, S., Tanaka, K., Takatsuji, T., Hoshi, M., Fukutani, S., Ditchburn, R.G. and Zondervan, A., 2008, A preliminary study on the use of ${ }^{10} \mathrm{Be}$ in forensic radioecology of nuclear explosion sites. Journal of Environmental Radioactivity, 99, 260-270.

Willenbring, J.K. and von Blanckenburg, F., 2010, Long-term stability of global erosion rates and weathering during late-Cenozoic cooling. Nature, $\mathbf{4 6 5}, 211-214$.
Winkler, R., Dietl, F., Frank, G. and Tschiersch, J., 1998, Temporal variation of ${ }^{7} \mathrm{Be}$ and ${ }^{210} \mathrm{~Pb}$ size distributions in ambient aerosol. Atmospheric Environment, 32, 983-991.

横山祐典, 阿瀬貴博, 村澤 晃, 松崎浩之, 2005, 宇宙線照射生 成核種を用いた地球表層プロセスの研究，地質学雑誌，111， 693-700.

Zapata, F., 2003, The use of environmental radionuclides as a tracers in soil erosion and sedimentation investigations: recent advances and future developments. Soil \& Tillage Research, 69, 3-13.

\section{ベリリウム同位体を用いる堆積学的研究}

金井 豊, 2014, 堆積学研究, Vol. 73, No. 1, 19-26

kanai, Y.: Sedimentological studies using beryllium isotopes

Jour. Sed. Soc. Japan, Vol. 73, No. 1, 19-26

環境中に存在しているべリリウムの放射性同位体である ${ }^{10} \mathrm{Be}$ 抢よび7 $\mathrm{Be}$ を, 堆積学・堆積地球化 学の分野に適用した研究例を紹介した。 また, 測定法についても解説を加えた。これらの核種は, その生成が地球大気中にあり定常的に地表面に降下して堆積していること, 粒子とともに挙動する ためそのトレーサーとして有用であること，放射性核種であるため「半減期」という時計を有してい ること, などの特質を利用して, 地表堆積物や海底堆積物の年代測定, 大陸侵食や土壤侵食・流出, 沿岸堆積物の新旧や挙動解明などの研究例があり, Be の同位体を用いる応用研究は様々な分野で広 がりつつある。 